Doporučené postupy vycházejí ze soudobých poznatků lékařské vědy a považují se za postupy lege artis. Jedná se však o doporučení, nikoli předpisy, proto je nutný individuální přístup u každého nemocného. Ošetřující lékař může použít jiný postup, musí však v dokumentaci řádně zdůvodnit, proč se od doporučeného postupu odchýlil.

\title{
Zásady pro implantace kardiostimulátorů, implantabilních kardioverterů-defibrilátorů a systémů pro srdeční resynchronizační léčbu 2009
}

Pracovni skupiny arytmie a trvalá kardiostimulace České kardiologické společnosti

\author{
Doporučení vypracovali členové výboru Pracovní skupiny arytmie a trvalá kardiostimulace \\ České kardiologické společnosti ve složení: \\ Miloš Táborský (milos.taborsky@seznam.cz) \\ Josef Kautzner (joka@medicon.cz) \\ Jan Bytešník (jan.bytesnik@ikem.cz) \\ Robert Čihák (roci@medicon.cz) \\ Luděk Haman (haman@fnkh.cz) \\ Petr Heinc (petr.heinc@fnol.cz) \\ Milan Kozák (mkozak@fnbrno.cz) \\ Luboš Křivan (krivan@fnbrno.cz) \\ Kateřina Lefflerová (kale@medicon.cz) \\ Jan Lukl (jan.lukl@fnol.cz) \\ Miroslav Pšenička (m.psenicka@centrum.cz) \\ Lucie Šedivá (lucie.sediva@homolka.cz) \\ Jitka Vlašínová (jvlasinova@fnbrno.cz) \\ Miroslav Tauchman (tauchmil@fnhk.cz)
}

Inovované Zásady pro implantace kardiostimulátorů, implantabilních kardioverterů-defibrilátorů a srdeční resynchronizační léčbu představují konsensus odborníků v arytmologii a odrážejí nová Doporučení Evropské kardiologické společnosti, která byla vytvořena ve spolupráci s Evropskou arytmologickou asociací. ${ }^{(1)}$ Dále vycházejí z aktuálních doporučení amerických kardiologických společností AHA/ACC/HRS. ${ }^{(2)}$ Současně jsou inovovanou verzí Zásad publikovaných Pracovní skupinou arytmie a trvalá kardiostimulace (PS AKS) České kardiologické společnosti (ČKS $)^{(3)}$ a reprezentují současné znalosti o léčbě poruch srdečního rytmu nebo srdečního selhání pomocí implantabilních přístrojů.

\section{Primární a sekundární prevence kardiovaskulárních onemocnění}

V oblasti trvalé kardiostimulace, srdeční resynchronizační léčby a implantací implantabilních kardioverterů-defibrilá- 
torů nemá primární a sekundární prevence žádná specifika. Je zcela ve shodě se zásadami prevence ischemické choroby srdeční tak, jak je uvedeno v „Doporučeních prevence kardiovaskulárních onemocnění ČKS“.

\section{Zásady diagnostiky supraventrikulárních a komorových arytmií}

Jsou shrnuty v dokumentu „Doporučení pro diagnostiku a léčbu supraventrikulární arytmií, fibrilace síní a komorových tachykardií", které vytvořila PS AKS ČKS. Nejsou proto náplní současných „Zásad pro implantace kardiostimulátorů, implantabilních kardioverterů-defibrilátorů a srdeční resynchronizační léčbu“.

\section{Zásady farmakoterapie supraventrikulárních a komorových arytmií}

Pro strategii farmakoterapie platí rovněž „Doporučení pro diagnostiku a léčbu supraventrikulárních arytmií, fibrilace síní a komorových tachykardii““ stejně jako v bodě 2 .

\section{Zásady nemedikamentózní léčby pomocí implantabilních prístrojů a její indikace}

Indikace implantací kardiostimulátorů (KS), implantabilních kardioverterů-defibrilátorů (ICD) a srdeční resynchronizační léčby (SRL).

\section{1. Úvod}

Trvalá kardiostimulace (TKS) se k léčbě bradykardií používá už více než padesát let. $\mathrm{V}$ průběhu tohoto období byla její účinnost ve smyslu ovlivnění kvality života, morbidity a mortality potvrzena objektivně, a to jak na základě klinické praxe, tak i na základě řady randomizovaných studií. ${ }^{(4-8)}$

Během poslední dekády se stala TKS v podobě SRL uznávanou léčebnou metodou pro pacienty s pokročilým srdečním selháním refrakterním na optimalizovanou medikamentózní léčbu a s poruchou nitrokomorového vedení vzruchu.

Přehled indikací představuje souhrn diagnóz a klinických stavů, u kterých je indikace TKS, ICD a SRL jednoznačně indikována.

Algoritmus indikace $\mathrm{k}$ TKS je nadále postaven na třech rovnocenných principech

1. Splnění indikačního kritéria podle diagnózy;

2. Výběr vhodného stimulačního režimu;

3. Klinický stav pacienta (přítomnost onemocnění limitujících prognózu, mobilita, psychický stav a další).

Vlastní indikace je výsledkem komplexního posouzení výše uvedených faktorů s přihlédnutím k ovlivnění kvality života a snížení rizika následných komplikací. Věk pacien- ta není sám o sobě limitujícím faktorem pro výběr typu stimulačního režimu. Konečné rozhodnutí týkající se péče o jednotlivé pacienty je v kompetenci lékaře, který je za tuto péči odpovědný.

\subsection{Indikace TKS při dysfunkci sinusového uzlu}

Po stanovení diagnózy dysfunkce sinusového uzlu je otázkou, zda u pacienta indikovat vždy TKS. Dlouhodobá klinická zkušenost spolu s řadou studií prokázala, že kardiostimulace $v$ tomto prrípadě zlepšuje především kvalitu života a omezuje výskyt epizod fibrilace síní, ${ }^{(9,10)}$ aniž by ovlivnila celkovou mortalitu. ${ }^{(11,12)}$

Indikace TKS jsou v případě syndromu chorého sinu podloženy důkazy $\mathrm{z}$ dostupné starší i novější literatury a jsou uvedeny v tabulce č. 4.2.1. Je důležité poznamenat, že $\mathrm{v}$ př́padě výskytu fibrilace síní v rámci této diagnózy, je nutné důkladně zvažovat perorální antikoagulační terapii. $^{(13)}$

Výsledky prospektivních randomizovaných studií ${ }^{(14,15)}$ dále dokumentují, že u pacientů s dysfunkcí sinusového uzlu záleží při TKS na volbě stimulačního režimu. Komorová stimulace je provázena signifikantně vyšším výskytem fibrilace síní než stimulace fyziologická (tj. stimulace síní nebo dvoudutinová stimulace). Současně zvyšuje komorová stimulace riziko vzniku tzv. pacemakerového syndromu. ${ }^{(15)}$

Pro výběr stimulačního režimu a př́istroje je nově doporučováno používat síňovou stimulaci nebo dvoudutinovou stimulaci s algoritmy omezujícími zbytečnou stimulaci pravé komory. Vzhledem k časté chronotropní inkompetenci je obvykle indikována frekvenčně reagující stimulace. Dále je možno využít i řadu algoritmů zaměřených na potlačení supraventrikulárních arytmií. Lze uvažovat i o alternativním umístění síňové elektrody do oblasti síňového septa. Naopak, nelze doporučit izolovanou komorovou simulaci. Pokud jde o výběr mezi stimulací síňovou nebo dvoudutinovou ( $\mathrm{tj}$. mezi implantací kardiostimulátoru AAI nebo DDD), záleží především na výši rizika rozvoje atrioventrikulární blokády a na výskytu fibrilace síní.

U dvoudutinové stimulace byl zaznamenán trend prodloužení průměrné délky života nemocných současně se zlepšením kvality života ve srovnání s komorovou stimulací, a to za všeobecně přijatelnou cenu. ${ }^{(16)}$

Tabulka 4.2.1.

1. Dysfunkce sinusového uzlu s dokumentovanou symptomatickou bradykardií. U některých pacientů je tento stav důsledkem dlouhodobé nezbytné medikamentózní terapie bez možnosti změnit dávkování nebo použít alternativní terapii.

2. Dysfunkce sinusového uzlu, vyskytující se spontánně nebo jako důsledek nezbytné medikamentózní terapie s bradykardií a srdeční frekvencí nižší než 40/min, kde není jasně dokumentován vztah mezi symptomatologií a prítomností bradykardie.

3. Symptomatická chronotropní inkompetence bez klidové bradykardie. 


\subsection{Indikace TKS při získané atrioventrikulární (AV) blokádě u dospělých}

V př́padě kompletní AV blokády existuje řada nerandomizovaných studií, které dokumentují, že TKS vede k př́iznivému ovlivnění prognózy, zejména u nemocných se synkopami. $^{(17,18)}$

U AV blokády druhého stupně I. typu jsou indikace $\mathrm{k}$ trvalé kardiostimulaci sporné, s výjimkou př́ípadů, kde ke zpoždění vedení vzruchu dochází pod úrovní AV uzlu nebo kdy jsou přítomny symptomy. ${ }^{(19)}$ Někteří autoři však navrhují, aby se o implantaci kardiostimulátorů v této indikaci uvažovalo i v př́padech absence symptomatické bradykardie a dále u nemocných bez průkazu organického postižení srdce. TKS totiž u starších asymptomatických pacientů signifikantně zlepšuje přežití, zejména pokud k AV blokádě druhého stupně I. typu dochází ve dne. ${ }^{(20)}$

Pacienti s AV blokádou druhého stupně II. typu, zejména při současném rozšíření komplexu QRS, mají zvýšené riziko rozvoje kompletní srdeční blokády a manifestace symptomů. ${ }^{(21)}$ Proto se u nich doporučuje TKS vždy.

U pacientů s AV blokem prvního stupně se kardiostimulace nedoporučuje. Výjimkou jsou případy výrazného prodloužení intervalu PQ (obvykle > $300 \mathrm{~ms}$ ), kdy nedochází při zátěži $\mathrm{k}$ jeho přiměřenému zkrácení a objevují se symptomy (tzv. pseudopacemakerový syndrom podle obdobného charakteru obtíží, které vznikají při komorové stimulaci u nemocných se zachovalým retrográdním vedením na síně). $\mathrm{V}$ těchto př́padech prokázaly malé, nekontrolované studie zlepšení kvality života. ${ }^{(22)}$

Před vlastní indikací TKS je nutné zkontrolovat, zda není příčina AV blokády reverzibilní (akutní infarkt myokardu, elektrolytová dysbalance nebo léky indukovaná AV blokáda, spánková apnoe, perioperační hypotermie, zánět nebo vagotonie způsobená přechodnými faktory). Indikační kritéria TKS pro AV blokádu jsou uvedena v tabulce 4.3.1.

Tabulka 4.3.1.

1. Kompletní AV blokáda, trvalá či intermitentní, bez rozdílu v anatomické lokalizaci, spojená alespoň s jednou z následujićích situací:

a) symptomatická bradykardie

b) městnavá slabost srdeční

c) ektopické rytmy vyžadující terapii, která vede ke snižení automacity náhradního centra se vznikem následující symptomatické bradykardie

d) záchyt asystolie $>3 \mathrm{~s}$ nebo záchyt poklesu srdeční frekvence $<40 / \mathrm{min}$, a to i u dosud zcela asymptomatického nemocného

e) neuromuskulární onemocnění provázená charakteristicky AV blokádou (např. muskulární dystrofie, syndrom Kearns-Sayre, Erbova dystrofie, peroneální muskulární atrofie apod.).(12-14)

f) stavy po ablaci AV junkce nebo chlopenní chirurgii

2. AV blokáda II. stupně, trvalá či intermitentní, nemající omezení $\checkmark$ lokalizaci nebo typu blokády, spojená se symptomatickou bradykardií.

3. Fibrilace síní, flutter síní nebo méně časté príipady supraventrikulární tachykardie spojené s pokročilou nebo kompletní AV blokádou, bradykardií a stavy popsanými v tabulce 4.2.1. Bradykardie nesmí být vyvolána digitalisem nebo jinými léky ovlivňujícími AV vedení, pokud tato terapie není nezbytná.
Tabulka 4.3.1. pokračování

4. Asymptomatická AV blokáda II. stupně II. typu (Mobitz), trvalá či intermitentní.

5. Asymptomatická AV blokáda II. stupně I. typu (Wenckebach) na úrovni intra- či infrahisální, prokázaná elektrofyziologicky.

6. Symptomatická trvalá AV blokáda I. stupně spojená s bradykardií nebo bifascikulární či trifascikulární blokádou s nutností vyloučení vlivu medikace ovlivňující AV vedení, pokud tato terapie není nezbytná.

7. Symptomatická AV blokáda I. stupně spojená se symptomy pseudopacemakerového syndromu, které prokazatelně mizí při zavedení dočasné AV sekvenční stimulace.

8. AV blokáda I. stupně u nemocných s těžkou dysfunkcí levé komory, ejekční frakce $(E F)<0,35$, a projevy pokročilého srdečního selhání (NYHA III-IV), kteři jsou indikováni k provedení AV sekvenční, resp. biventrikulární stimulace $z$ hemodynamických důvodů (viz bod 4.12.1.-2).

\subsection{Indikace TKS u AV blokády spojené s akutním infarktem myokardu}

Metaanalýza čtyř rozsáhlých randomizovaných klinických studií (GUSTO-I, GUSTO-IIb, GUSTO-III a ASSENT-II), která shrnuje údaje 75993 pacientů, prokázala rozvoj AV blokády téměř v $7 \%$ prŕpadů akutního infarktu myokardu (AIM). ${ }^{(23)}$ Pacienti s AV blokádou v období AIM vykazují vyšší nemocniční a následnou mortalitu $\mathrm{v}$ porovnání s nemocnými se zachovalým $\mathrm{AV}$ vedením. ${ }^{(24)}$

Charakter a prognóza poruch vedení, které jsou spojeny s AIM, se od jiných forem poruch vedení poněkud liší. Indikace $\mathrm{k}$ TKS u AIM proto není nutně závislá na př́tomnosti symptomů a je $\mathrm{v}$ řadě př́padů podmíněna kombinací AV blokády s poruchou intraventrikulárního vedení. ${ }^{(25)}$ U pacientů s AIM spodní stěny mohou být poruchy atrioventrikulárního vedení přechodné a jsou často dobře tolerovány. ${ }^{(26)} \mathrm{Za}$ těchto okolností není implantace kardiostimulátoru obvykle nutná. Doporučení ohledně TKS při přetrvávající $\mathrm{AV}$ blokádě (delší než 10 dnů) ve spojitosti s AIM jsou shrnuta v tabulce č. 4.4.1.

Tabulka 4.4.1.

1. Kompletní AV blokáda trvající déle než 10 dnů po vzniku AIM.

2. AV blokáda II. stupně nebo kompletní AV blokáda spojená s blokádou na úrovni Hisova-Purkyňova systému, přetrvávající déle než 10 dnů po vzniku AIM.

3. Přechodná AV blokáda vyššího stupně spojená s nově vzniklou blokádou Tawarova raménka.

\subsection{Indikace TKS při bifascikulární a trifascikulární blokádě}

U asymptomatických pacientů s bifascikulární nebo trifascikulární blokádou se TKS považuje za indikovanou pouze $\mathrm{v}$ případě přechodné $\mathrm{AV}$ blokády druhého a třetího stupně, nebo jsou-li př́tomny známky závažné poruchy nitrokomorového vedení vzruchu (HV > 100 ms nebo 
elektrofyziologicky prokázaná intra-, resp. infrahisální blokáda). Tito nemocní mají vysoké riziko rozvoje kompletní AV blokády a TKS je indikována k prevenci rozvoje symptomů. V současné době není známo, zda může TKS ovlivnit prŕżnivě jejich prognózu. ${ }^{(27)}$

U nemocných se synkopami a blokádou Tawarova raménka se předpovídá nález jednoznačných abnormalit vedení Purkyňovým a Hisovým systémem s rozvojem trvalé AV blokády asi u $87 \%$ pacientů. ${ }^{(28)}$ Podobně u pacientů s neuromuskulárními onemocněními a fascikulární blokádou jakéhokoli charakteru je TKS jednoznačně indikována, a to bez ohledu na prítomnost nebo chybění symptomů. ${ }^{(29,30)}$ $\mathrm{V}$ takových případech totiž nelze předpovědět progresi poruchy atrioventrikulárního vedení.

Indikace TKS u chronické bifascikulární a trifascikulární blokády jsou shrnuty v tabulce 4.5.1.

Tabulka 4.5.1.

1. Bifascikulární, resp. trifascikulární blokáda s prèechodnou kompletní AV blokádou bez nezbytných symptomů doprovázejících srdeční blokádu.

2. Bifascikulární, resp. trifascikulární blokáda s přechodnou AV blokádou II. stupně II. typu (Mobitz) bez nezbytných symptomů doprovázejících srdeční blokádu.

3. Bifascikulární, resp. trifascikulární blokáda se synkopou i při vyloučení AV blokády a jiných stavů, zejména komorové tachykardie, jako možné prířiny.

4. Bifascikulární, resp. trifascikulární blokáda spojená s nálezem signifikantně prodlouženého HV intervalu ( $\geq 100 \mathrm{~ms}$ ) při elektrofyziologickém vyšetření u asymptomatických pacientů.

5. Bifascikulární, resp. trifascikulární blokáda se stimulací indukovanou infrahisální nebo intrahisální blokádou během elektrofyziologického vyšetření.

HV - interval mezi aktivací Hisova svazku a komorovou aktivací

\subsection{Indikace TKS při hypersenzitivitě karotického sinu a neurokardiálních synkopách}

První práce o prŕínnivém ovlivnění synkop u pacientů se syndromem hypersenzitivity karotického sinu pomocí TKS se objevily v 70. letech dvacátého století. ${ }^{(31)}$ Následující studie ${ }^{(32,33)}$ prokázaly, že TKS vede u těchto pacientů $\mathrm{k}$ významnému snížení počtu synkop. Od farmako-terapie syndromu hypersenzitivity karotického sinu se proto upustilo. ${ }^{(34)}$ TKS je v současnosti jediným způsobem léčby přinášejícím těmto pacientům zlepšení kvality života.

TKS u opakovaných neurokardiálních synkop je indikována u nemocných, u nichž byl pomocí holterovského monitorování nebo testu na nakloněné rovině, příp. pomocí implantabilního záznamníku, dokumentován opakovaný výskyt protrahované asystolie. $\mathrm{V}$ každém př́padě je nutné zdůraznit, že rozhodnutí ohledně implantace kardiostimulátoru musí být provedeno v kontextu klinického obrazu onemocnění, které často postihuje mladé jedince. $\mathrm{V}$ těchto případech je vždy třeba přihlížet $\mathrm{k}$ očekávanému př́nosu TKS ve srovnání s možnými dlouhodobými komplikacemi této léčby. Indikace TKS u hypersenzitivity karotického sinu a neurokardiálních synkopách jsou shrnuty v tabulce 4.6.1.

Tabulka 4.6.1.

1. Opakovaná neurokardiální synkopa s protrahovanou asystolií na EKG nebo při testu na nakloněné rovině (HUTT), refrakterní na medikamentózní léčbu.

2. Opakovaná synkopa, indukovaná masáží karotického sinu, kdy minimální tlak na karotický sinus vyvolá asystolii > 3 s nebo významný pokles srdeční frekvence doprovázený symptomatologií s vyloučením vlivu medikace, která působí depresivně na sinoatriální či $A V$ vedení.

3. Kardioinhibiční odpověd' na masáž karotického sinu s výskytem symptomů u nemocného s jinak neobjasněnými synkopami v anamnéze.

\subsection{Indikace TKS u syndromu spánkové apnoe}

Syndrom spánkové apnoe/hypopnoe je velmi častou poruchou dýchání, která postihuje $4 \%$ mužů a $2 \%$ žen ve středním věku. ${ }^{(35)}$ Jak centrální, tak i obstrukční typ této poruchy jsou spojeny se zvýšenou kardiovaskulární morbiditou a mortalitou. ${ }^{(36,37)}$ Indikace TKS u syndromu spánkové apnoe jsou uvedeny v tabulce 4.7.1.

Tabulka 4.7.1.

Dokumentovaná bradykardie nebo paroxysmální supraventrikulárn tachykardie spojená s apnoickými pauzami nebo hypopnoe, centrálního či obstrukčního původu, které nejsou ovlivnitelné jinými léčebnými postupy.

\subsection{Indikace TKS u dětí}

Přes svou podobnost s indikacemi u dospělých tvoří indikace $\mathrm{k}$ TKS u dětí a dospívajících samostatnou kapitolu. Rozhodnutí o TKS záleží na věku a symptomech pacienta, druhu onemocnění a jeho přirozeném průběhu, a na př́ítomnosti vrozeného strukturálního postižení srdce. ${ }^{(38-43)}$ Způsob implantace (endokardiální nebo epikardiální) a výběr optimálního stimulačního režimu je ovlivněn přítomností intrakardiálních zkratů nebo ohledem na šetrnost výkonu při současné snaze o dlouhodobé zachování cévního přístupu vzhledem k perspektivě celoživotní kardiostimulace. Indikace TKS u dětí jsou uvedeny v tabulce 4.8.1.

Tabulka 4.8.1.

1. Dysfunkce sinusového uzlu se symptomatickou bradykardií včetně stavu, kdy bradykardie je důsledkem nezbytné antiarytmické terapie.

2. Asymptomatická sinusová bradykardie u dítěte s komplexní vrozenou srdeční vadou s klidovou srdeční frekvencí < 40/min nebo pauzami v komorovém rytmu delšími než $3 \mathrm{~s}$.

3. Brady-tachykardický syndrom po kardiochirurgickém výkonu s nutností léčby antiarytmiky (s výjimkou digoxinu). 
Tabulka 4.8.1. pokračování

4. Pokročilá AV blokáda II. či III. stupně spojená se symptomatickou bradykardií, dysfunkcí komor nebo se známkami nízkého srdečního výdeje.

5. Vrozená AV blokáda s náhradním rytmem se širokým komplexem QRS při infrahisární lokalizaci blokády.

6. Novorozenci a kojenci s kompletní vrozenou AV blokádou a komorovou frekvencí < 50-55/min při absenci hemodynamicky významné vrozené srdeční vady nebo $<70 /$ min při hemodynamicky významné vrozené srdeční vadě.

7. Kongenitální AV blokáda III. stupně u pacientů starších než jeden rok $s$ průměrnou denní komorovou frekvencí ( $v$ bdělém stavu) méně než 50/min, náhlými pauzami v komorovém rytmu v délce dvou- až trojnásobku základní délky cyklu, nebo se známkami chronotropní inkompetence.

8. Kompletní AV blokáda s dokumentovanými pauzami delšími než 3 s nebo s minimální variabilitou srdeční frekvence

9. Pokročilá AV blokáda II. stupně či AV blokáda III. stupně přetrvávající více než 7-14 dní po provedené srdeční operaci.

10. Komplexní komorové arytmie spojené s AV blokádou II. či III. stupně nebo sinusovou bradykardií.

11. Zevní oftalmoplegie s bifascikulární blokádou.

12. Kongenitální atrioventrikulární blokáda a prodloužený interval QT.

\subsection{Indikace TKS u dospělých $s$ vrozenými srdečními vadami}

Počet dospělých $s$ vrozenými srdečními vadami roste. $\mathrm{V}$ důsledku možnosti chirurgické nápravy nebo zmírnění vrozených srdečních vad v dětství se dospělosti dožívá $85 \%$ dětí narozených s vrozenými srdečními vadami. Mnozí z nich potřebují v důsledku provedeného chirurgického výkonu celoživotní TKS. U jiných může být TKS potřeba později, např. $\mathrm{k}$ omezení výskytu síňových arytmií nebo $\mathrm{v}$ rámci hybridní léčby. $\mathrm{V}$ současnosti došlo $\mathrm{k}$ poklesu incidence chirurgické AV blokády vzniklé po nápravě septálních defektů a Fallotovy tetralogie. Tento pokles je však vyrovnáván nárůstem kardiostimulace po nápravě komplikovaných defektů. Důležitou skupinu pacientů vyžadujících TKS tvoří nemocní po složitých korekcích v oblasti síní, např. v průběhu Fontanovy, Mustardovy a Senningovy operace. ${ }^{(44-47)}$ $S$ bradyarytmiemi i tachyarytmiemi se u nich setkáváme jak $\mathrm{v}$ časném pooperačním období, tak zejména $\mathrm{v}$ průběhu dlouhodobého sledování. Indikace TKS odpovídají standardním indikacím s přihlédnutím $\mathrm{k}$ možným technickým obtížím implantace v důsledku žilních anomálií, předchozího chirurgického výkonu nebo úplné obstrukce žilního př́istupu.

\subsection{Indikace TKS u nemocných po transplantaci srdce}

TKS u pacientů po transplantaci srdce může sledovat tři cíle:

> zajištění chronotropní kompentence,

> zachování synchronní kontrakce komor ke zlepšení mechanické práce srdce,

> neinvazivní sledování rejekce štěpu.
V období následujícím bezprostř̌edně po transplantaci se často vyskytují bradyarytmie, se kterými se setkáváme až u $64 \%$ transplantovaných. ${ }^{(48,49)}$ Četnost implantací trvalého kardiostimulátoru se liší v závislosti na použitých indikačních kritériích a pohybuje se mezi 2,8 až $29 \% .^{(50)}$

Indikační kritéria $\mathrm{k}$ TKS po transplantací srdce nejsou v současné době zcela jednoznačná. Odborníci se shodují na tom, že TKS potřebují pacienti, u kterých přetrvává bradyarytmie navzdory podávání teofylinu více než tři týdny po operaci. Doporučené indikace pro TKS po transplantaci srdce jsou uvedeny v tabulce 4.10.1.

Tabulka 4.10.1

1. Symptomatické bradyarytmie způsobené dysfunkcí sinoatriálního uzlu nebo atrioventrikulární blokádou, pretrvávající minimálně tři týdny po transplantaci srdce.

2. Přetrvávající symptomatická chronotropní inkompetence.

3. Symptomatické bradyarytmie mezi prvním a třetím týdnem po transplantaci s významnými hemodynamickými důsledky.

\subsection{Indikace TKS u nemocných s hypertrofickou kardiomyopatií}

Principem terapeutického účinku TKS u hypertrofické obstrukční kardiomyopatie je změna průběhu komorové kontrakce $\mathrm{v}$ důsledku regionální dyssynchronie (desynchronizace) navozené stimulací hrotu pravé komory. Změna charakteru aktivace levé komory s pozdní aktivací bazálních částí septa a sníženou kontraktilitou ${ }^{(51-53)}$ levé komory vedou ke zvětšení systolického rozměru levé komory a snížení systolického dopředného pohybu mitrální chlopně. Konečným důsledkem je pokles tlakového gradientu ve výtokovém traktu levé komory. Žádoucí preexcitace hrotu pravé komory je možné dosáhnout pomocí stimulace v režimu DDD s krátkým AV zpožděním. V případech, kdy je stimulace možná jen při výrazně zkráceném AV zpoždění, je možné indikovat ablaci AV junkce a umožnit tak optimalizaci plnění levé komory prodloužením AV zpoždění.

O dlouhodobé účinnosti TKS u pacientů s hypertrofickou kardiomyopatií existují zatím nejednoznačné údaje. Skutečnost, že gradient ve výtokovém traktu levé komory zůstává snížen i po ukončení období stimulace naznačuje, že tato léčba vede ke komorové remodelaci. ${ }^{(54,55)}$ Neexistuje však důkaz, který by potvrzoval, že v důsledku kardiostimulace dochází k menšímu zesílení septa. Není také jasné, jak předpovědět dlouhodobou účinnost této léčby u konkrétního pacienta. Snížení gradientu ve výtokovém traktu levé komory totiž nemusí korelovat se zmírněním symptomů. ${ }^{(56-58)}$ TKS může být indikována i u pacientů bez obstrukce výtokového traktu, a to $\mathrm{k}$ ovlivnění symptomatické bradykardie navozené podáváním léků. Indikace TKS u hypertrofické obstrukční kardiomyopatie jsou uvedeny $\mathrm{v}$ tabulce 4.11.1. 
Tabulka 4.11.1.

1. Symptomatická bradykardie v důsledku podávání beta-blokátorů v prípadě, že alternativní léčba není možná.

2. Pacienti s hypertrofickou obstrukční kardiomyopatií a významným tlakovým gradientem ve výtokovém traktu levé komory v klidu nebo po lékové provokaci, který přetrvává i při podávání lékủ s negativním účinkem na kontraktilitu myokardu a při nemožnosti provedení alkoholové septální ablace nebo chirurgické myektomie.

\subsection{Srdeční resynchronizační léčba}

Srdeční resynchronizační léčba (SRL) patří dnes mezi standardní postupy nefarmakologické léčby pokročilého srdečního selhání. Jednoznačný průkaz klinického účinku SRL poskytují randomizované studie u pacientů s rozšíŕeným komplexem QRS $\geq 120$ ms, jako známkou významné poruchy nitrokomorového vedení vzruchu. Tato porucha je u většiny pacientů provázena dyssynchronií mechanické kontrakce, která je korigovatelná SRL. ${ }^{(59)} \mathrm{V}$ současnosti neexistují důkazy o tom, že SRL může být indikována i u pacientů se srdečním selháním a šírí komplexu QRS $<120 \mathrm{~ms}$, a to přes opakovaný průkaz mechanické dyssynchronie pomocí zobrazovacích metod. ${ }^{(60-63)}$ Podobně nejsou důkazy o tom, že by bylo možno zlepšit dlouhodobou účinnost SRL výběrem pacientů na základě echokardiografického vyšetření nebo jiné diagnostické metody. ${ }^{(63)}$

Podobně pokračují odborné diskuse o tom, zda nemocným indikovaným $\mathrm{k}$ SRL implantovat biventrikulární kardiostimulátor nebo kardioverter-defibrilátor s možností biventrikulární stimulace. Indikace $\mathrm{k}$ implantacím biventrikulárního kardiostimulátoru nebo ICD s možností biventrikulární stimulace se do určité míry překrývají. Přestože SRL za použití kardiostimulátoru zlepšuje prokazatelně prognózu nemocných, hromadí se údaje o tom, že implantace ICD s možností biventrikulární stimulace snižuje navíc výskyt náhlé srdeční smrti. Na druhé straně existují údaje, které dokumentují, že př́nos ICD může být velmi omezený $\mathrm{v}$ případě existence závažných komorbidit. $\mathrm{V}$ nejnovějších doporučeních týkajících se náhlé srdeční smrti ${ }^{(64)}$ se proto zdůrazňuje, že při indikaci ICD v rámci primární prevence je nutné přihlížet $\mathrm{k}$ očekávanému přežití pacienta, což zahrnuje všeobecný stav pacienta, zejména v závislosti na biologickém věku a výskytu důležitých doprovodných onemocnění, která by mohla mít vliv na jeho prognózu. $\mathrm{V}$ těchto doporučeních se výslovně stanovuje, že použití ICD za účelem primární prevence je indikováno u pacientů se srdečním selháním se závažnou dysfunkcí levé komory bez ohledu na základní onemocnění, „u kterých můžeme důvodně předpokládat dobu přežití > jeden rok“ ${ }^{\text {“(64) }}$ Indikace SRL jsou uvedeny v tabulce 4.12.1.

Tabulka 4.12.1

1. Srdeční selhání ischemické i neischemické etiologie, funkční trídy NYHA III-IV, s významnou dilatací a systolickou dysfunkcí levé komory srdeční (end-diastolický rozměr levé komory > $55 \mathrm{~mm}$ a ejekční frakce levé komory $\leq 35 \%$ ), sinusovým rytmem a šírí komplexu QRS $\geq 120 \mathrm{~ms}$, a to po vyčerpání možností standardní terapie.
Tabulka 4.12.1. pokračováni

2. Srdeční selhání ischemické i neischemické etiologie funkční třídy NYHA III-IV, s významnou dilatací a systolickou dysfunkcí levé komory srdeční (end-diastolický rozměr levé komory $>55 \mathrm{~mm}$ a ejekční frakce levé komory $\leq 35 \%$ ) a současnou indikací $k$ TKS.

3. Srdeční selhání ischemické i neischemické etiologie funkční třídy NYHA III-IV, s významnou dilatací a systolickou dysfunkcí levé komory srdeční (end-diastolický rozměr levé komory $>55 \mathrm{~mm}$ a ejekční frakce levé komory $\leq 35 \%$ ) a indikací k implantaci ICD (4.14.1.-7.).

4. Srdeční selhání ischemické i neischemické etiologie, funkční třídy NYHA III-IV, s významnou dilatací a systolickou dysfunkcí levé komory srdeční (end-diastolický rozměr levé komory $>55 \mathrm{~mm}$ a ejekční frakce levé komory $\leq 35 \%)$ s permanentní fibrilací síni v případě rozšírení komplexu QRS $\geq 120$ ms a vyčerpání možností standardní terapie, nebo při jakékoli šíri komplexu QRS při indikaci k ablaci AV junkce.

5. Indikace $\mathrm{k}$ SRL a současnému kardiochirurgickému výkonu, kdy lze implantovat levokomorovou elektrodu na laterální stěnu levé komory peroperačně.

\subsection{Indikace TKS v souvislosti s kardiochirurgickými výkony}

Kritéria indikace TKS u nemocných po provedení kardiochirurgických výkonů odpovídají indikacím uvedeným $\mathrm{v}$ bodech 4.2.-4.12. S ohledem na údaje o normalizaci poruch srdečního rytmu po těchto výkonech $\mathrm{v}$ časném pooperačním období je pro indikaci TKS nutná trvalá přitomnost poruchy srdečního rytmu po dobu minimálně sedmi dnů. ${ }^{(65,66)}$

\subsection{Indikace k implantaci ICD}

Indikace $\mathrm{k}$ implantacím ICD jsou podloženy výsledky řady velkých randomizovaných studií, které jasně prokázaly účinnost této léčby jak v oblasti sekundární, tak i primární prevence náhlé srdeční smrti. ${ }^{(67-82)}$ Přes dlouhodobé úsilí zpřesnit stratifikaci rizika náhlé srdeční smrti u ischemických i neischemických kardiomyopatií, zůstává stanovení ejekční frakce levé komory stále zlatým standardem. Léčba pomocí ICD významně ovlivňuje nejen přežívání pacientů, ale i kvalitu jejich života (použití antitachykardické stimulace bez nutnosti kardioverze, redukce hospitalizací pro opakované komorové tachykardie nebo ve spojení s biventrikulární stimulací pro ovlivnění pokročilého srdečního selhání aj.). Kromě toho dlouhodobě snižuje náklady na léčbu těchto nemocných. ${ }^{(83)}$

Implantace ICD není indikována u nemocných s předpokladem přežití méně než jeden rok nebo u nemocných, kde byl vznik komorové tachykardie, resp. fibrilace komor, podmíněn prokazatelně přechodnými př́íčnami. Podobně není implantace ICD indikována u nemocných s pokročilým srdečním selháním ve funkční třídě NYHA IV, pokud není současně indikace $\mathrm{k}$ SRL (4.12.1.).

Při indikaci $\mathrm{k}$ této léčbě je třeba zvažovat nutnost komplexní péče o pacienta a připravenost pracoviště řešit možné komplikace (arytmická boư̌e, infekce systému, infrakce 
elektrod, technické problémy a další). Doporučení pro implantace ICD navazují na Doporučení pro léčbu komorových arytmií České kardiologické společnosti (www.kardio-cz.cz). Indikace $\mathrm{k}$ implantaci ICD jsou uvedeny v tabulce 4.14.1.

Nedílnou součástí indikačního protokolu je snaha o přesnou definici arytmogenního substrátu s nutností provedení selektivní koronarografie, př́ípadně dalších vyšetření (viabilita myokardu atd.). Tam, kde je na základě koronarografického nálezu indikováno provedení revaskularizačního výkonu (chirurgického nebo perkutánního), popř. komplexního kardiochirurgického výkonu (náhrada chlopně, remodelační operace levé komory aj.) považujeme tento výkon za prioritní. Posouzení nutnosti implantace ICD po výkonu je nutné individualizovat s přihlédnutím ke konkrétní situaci. Vždy je nutno zvážit možnost současného provedení katetrizační nebo chirurgické ablace.

Tabulka 4.14.1.

I Sekundární prevence:

1. Oběhová zástava na podkladě dokumentované fibrilace komor nebo setrvalé komorové tachykardie (tj. komorové tachykardie trvající déle než 30 s nebo vedoucí $k$ oběhové zástavě v čase kratším), a to po vyloučení reverzibilních přičíin - bez ohledu na základní onemocnění. Oběhová zástava nebo závažné symptomy (např. synkopa), u nichž jsou předpokládanou príčinou komorové arytmie, u nemocných zařazených do programu srdeční trasplantace (tzv. přemostění období do transplantace srdce).

2. Spontánní dokumentovaná setrvalá komorová tachykardie u nemocných se strukturálním postižením myokardu $(E F \quad L K \leq 0,40)$ $s$ vyloučením přechodných prríčin tohoto stavu, kdy není indikace k provedení katetrizační ablace, resp. chirurgické cílené léčby.

3. Synkopa nejasné etiologie u nemocného $s$ hemodynamicky závažnou komorovou tachykardií, resp. fibrilací komor indukovanou při programované stimulaci komor, nebo dokumentovanou během holterovského monitorování, prípadně ergometrického vyšetření. Podmínkou je vyloučení jiných prričin a provedení elektrofyziologického vyšetření.

II Primární prevence:

4. Dokumentované epizody nesetrvalé komorové tachykardie u nemocných s ischemickou chorobou srdeční, po infarktu myokardu, s dysfunkcí levé komory (ejekční frakce levé komory $\leq 0,40$ ) a indukcí setrvalé komorové tachykardie nebo fibrilace komor prì programované stimulaci komor za standardní farmakologické léčby po AIM (beta-blokátory).

5. Ischemická choroba srdeční s významnou poinfarktovou dysfunkcí levé komory (ejekční frakce levé komory $\leq 0,35$ ) ve funkční třídě NYHA II-III, po provedené revaskularizaci (je-li indikována), minimálně 40 dnů po AIM, a to za standardní farmakologické léčby po AIM (beta-blokátory). U nemocných s funkční klasifikací NYHA I pouze při hodnotě ejekční frakce levé komory $\leq 0,30$.

6. Neischemická kardiomyopatie s významnou dysfunkcí levé komory (ejekční frakce levé komory $\leq 0,35$ ) ve funkční tř́dě NYHA II-III navzdory optimalizované farmakologické léčbě a při nesplnění kritérií k SRL.

7. Srdeční selhání ischemické i neischemické etiologie s indikací k ICD (4.14.1.) a současnou indikací k SRL (jde o primoimplantaci nebo upgrade na jiný způsob stimulace při výměně přistroje) s významnou dilatací a systolickou dysfunkcí levé komory srdeční (end-diastolický rozměr levé komory $>55 \mathrm{~mm}$ a ejekční frakce levé komory $\leq 35 \%)$ (4.12.1.).

\section{Tabulka 4.14.1. pokračování}

8. Jedna nebo více dokumentovaných epizod komových tachykardií u nemocných, kde prokazatelně selhaly jiné léčebné postupy (antiarytmická léčba, katetrizační ablace, cílená chirurgická léčba), bez ohledu na základní onemocnění a dysfunkci levé komory.

III Speciální indikace:

9. Familiární či vrozené stavy s vysokým rizikem život ohrožujících komorových arytmií se synkopou nebo epizodou hemodynamicky závažné komorové tachykardie, resp. komorové fibrilace (idiopatická fibrilace komor, katecholaminergní polymorfní komorová tachykardie a rizikové formy těchto onemocnění: hypertrofická kardiomyopatie s prítomností minimálně jednoho rizikového znaku [oběhová zástava, dokumentovaná setrvalá komorová tachykardie, pozitivní rodinná anamnéza náhlé smrti, synkopa nejasné etiologie, hypertrofie $L K \geq 30 \mathrm{~mm}$, dokumentované nesetrvalé komorové tachykardie, abnormální tlaková reakce při zátěžovém vyšetření], syndrom dlouhého intervalu QT s prítomností minimálně jednoho rizikového faktoru [LQT1 a LQT2 s QTc > 500 ms, muži s LQT3 bez ohledu na trvání intervalu QTc], syndrom krátkého intervalu QT, Brugadův syndrom, syndrom předčasné repolarizace, arytmogenní kardiomyopatie pravé komory).

\subsection{Výběr vhodného stimulačního režimu, resp. typu kardiostimulátoru}

Nedílnou součástí indikace TKS je výběr optimálního stimulačního režimu (viz tabulku 4.15.1). Je třeba zdůraznit, že u mnoha nemocných je kardiostimulace indikována primárně ke zlepšení kvality života. Tu ovlivňuje příznivě tzv. fyziologická stimulace, napodobující normální sekvenci šírení vzruchu. Její preference spolu s omezením pravokomorové stimulace jsou důležitými aspekty v prevenci řady komplikací, ke kterým vede nesprávný výběr stimulačního režimu (např. pacemakerový syndrom, fibrilace síní, tromboembolické komplikace atd.). Tyto komplikace výrazným způsobem snižují kvalitu života nemocných a v konečném důsledku vyžadují změnu stimulačního režimu s nutností reoperace a výrazným zvýšením nákladů na výkon. ${ }^{(33-37)}$

Při výběru vhodného stimulačního režimu je nutno vycházet $\mathrm{z}$ posouzení následujících faktorů:

\section{A. Stav siño-komorového prevodu}

Vychází se ze stanovení tzv. Wenckebachova bodu (tj. stimulační frekvence, při které dochází ke vzniku AV blokády). Kontraindikací režimu síňové stimulace (AAI-R) je AV převod $1: 1<120 /$ min nebo př́tomnost raménkové blokády jako projevu poruchy nitrokomorového vedení vzruchu. Při průkazu dostatečné antegrádní převodní kapacity lze zvolit bud' síńovou stimulaci nebo dvoudutinovou stimulaci s algoritmy zajištujícími omezení komorové stimulace.

\section{B. Stanovení chronotropní kompetence}

Neschopnost dosažení maximální tepové frekvence při zátěži podle vzorce $0,7 \times(220$-věk $)$ je jednoduchou definicí chronotropní inkompetence a současně indikací $\mathrm{k}$ použití frekvenčně reagujícího kardiostimulátoru. Při volbě typu senzoru by se mělo přihližet $k$ obecným indikacím a kontraindikacím jednotlivých senzorů. Většinou se používá senzor reagujícího na pohyby těla (tj. na tělesnou 
aktivitu). Existují však i více fyziologické senzory, reagující na ventilaci, interval QT nebo na změny impedance $\mathrm{v}$ pravé komoře. Ve zvláštních případech lze využít i kombinace senzorů, která umožnuje optimální frekvenční odpověd', adekvátní zvýšení srdečního výdeje a maximální pracovní kapacity. Tyto typy kardiostimulátoru nejsou indikovány u zcela imobilních nebo minimálně mobilních nemocných.

\section{Přitomnost siňových arytmií}

Obecně platí, že chronická fibrilace síní nebo atypický síňový flutter jsou kontraindikací síňové stimulace. Při současném výskytu paroxysmálních síňových tachykardií je indikováno použití fyziologické dvoudutinové stimulace s funkcí „automatic mode switching/conversion“, která umožňuje změnu stimulačního režimu při detekci arytmie a zpětný návrat $\mathrm{k}$ fyziologické stimulaci při ukončení arytmie. Zejména v př́padech selhání farmakologické nebo ablační léčby mohou být použity specifické algoritmy detekce supraventrikulárních tachyarytmií a preventivní síňové stimulace, které mohou přispět $\mathrm{k}$ redukci paroxysmů arytmie.

\section{Retrográdní vedení}

Př́tomnost retrográdního vedení z komor na síně je naprostou kontraindikací izolované komorové stimulace pro vysoké riziko vzniku pacemakerového syndromu.

\section{E. Hemodynamické aspekty}

U pacientů s dysfunkcí levé komory je vždy nutno uvažovat o hemodynamickém dopadu stimulace. K prevenci progrese srdečního selhání je nutno zvažovat biventrikulární stimulaci. Podobně je nutné přemýšlet o optimalizaci místa stimulace $\mathrm{v}$ pravé komoře. Některé studie naznačují, že hemodynamicky výhodnější je stimulace z oblasti středního septa nebo výtokového traktu pravé komory.

\section{F. Indikace $k$ vyšetření magnetickou rezonancí}

$\mathrm{U}$ nemocných s indikací trvalé kardiostimulace, kde je př́tomno přidružené onemocnění, které by vyžadovalo vyšetření pomocí magnetické rezonance, je možné zvážit implantaci speciálního stimulačního systému. Ten dovoluje vyšetření magnetickou rezonancí provést. Jinak platí jednoznačné kontraindikace použití magnetické rezonance.

\subsection{Závěr}

Algoritmus indikace TKS, ICD a SRL představuje dynamicky se rozvíjející rozhodovací proces, jehož základem jsou aktuální poznatky o léčbě poruch srdečního rytmu; klade důraz na kvalitu života nemocných, prevenci závažných komplikací a při dodržení výše uvedených principů reprezentuje z dlouhodobého hlediska optimální poměr nákladů a prospěchu pro nemocného. Pracovní skupina Arytmie a trvalá kardiostimulace ČKS průběžně inovuje Zásady implantace kardiostimulátorů a implantabilních kardioverterů-defibrilátorů na základě nových poznatků v oboru s přihlédnutím k aktuálním doporučením Evropské kardiologické společnosti formou inovovaných verzí, resp. dodatků.

\section{Prognostické informace}

Oblast trvalé kardiostimulace představuje v České republice tradičně vysoce rozvinutou část kardiologie. V současné době existuje 38 implantačních center. Počet výkonů na jeden milion obyvatel dosáhl v roce 2008682 primoimplantací. Struktura implantací, resp. použité typy stimulačních režimů, jsou $\mathrm{v}$ posledních letech stabilizovány. Do budoucna lze očekávat nárůst počtu implantací v souvislosti s dalším rozvojem srdeční resynchronizační léčby a aplikace moderních technologií v oblasti trvalé kardiostimulace.

$\mathrm{Na}$ základě výsledků velkých randomizovaných studií došlo v oblasti implantabilních kardioverterů-defibrilátorů

Tabulka 4.15.1.

\begin{tabular}{|c|c|c|c|}
\hline Diagnóza & Stimulační režim optimální & Stimulační režim možný & Stimulační režim nevhodný \\
\hline Sick sinus syndrom & $\mathrm{DDD}(\mathrm{R})+\mathrm{MKS}$ & $\mathrm{AAl}(\mathrm{R})$ & VVI, VDD \\
\hline AV blokády & DDD & VDD & $\begin{array}{l}\text { AAI, DDI } \\
\text { VVI + VA kondukce }\end{array}$ \\
\hline SSS + AV blokáda nebo raménková blokáda & $\mathrm{DDD}(\mathrm{R}), \mathrm{DDIR}$ & $\mathrm{DDD}, \mathrm{DDI}$ & AAI, VVI \\
\hline Permanentní fibrilace síní, resp. atypický flutter síní & $\operatorname{VVI}(\mathrm{R})$ & VVI & AAl, DDD \\
\hline SSS nebo AV blokáda + paroxysmální síňové arytmie & $\mathrm{DDD}(\mathrm{R})+\mathrm{AMS}$ & DDIR, DDDRP + AMS & VDD, AAI \\
\hline $\begin{array}{l}\text { Neurokardiologická synkopa, syndrom } \\
\text { hypersenzitivity karotického sinu }\end{array}$ & $\begin{array}{l}\text { DDI + hysteréza príp. specifické } \\
\text { algoritmy akcelerace TF }\end{array}$ & DDD & AAl, VDD \\
\hline Srdeční resynchronizační léčba & DDDR/BiV & VVIR/BiV (FiS) & $\mathrm{AAl}, \mathrm{VVI}$ \\
\hline Hypertrofická kardiomyopatie & $\begin{array}{l}\text { DDD + optimalizované } \\
\text { AV zpoždění }\end{array}$ & $\begin{array}{l}\text { VDD, DDDR + } \\
\text { optimalizované AV zpoždění }\end{array}$ & $\mathrm{AAI}, \mathrm{VVI}$ \\
\hline Syndrom spánkové apnoe & $\mathrm{AAI} / \mathrm{R}$ & DDI & $\mathrm{DDD}, \mathrm{VVI}$ \\
\hline
\end{tabular}

BiV - biventrikulární stimulace, DDDRP - dvoudutinová frekvenčně reagující stimulace s užitím preventivních algoritmů síňové stimulace u nemocných s paroxysmální fibrilací síní, MKS - algoritmus minimalizace komorové stimulace, TF - tepová frekvence 
k významným změnám v indikacích, a to zejména v oblasti primárně-preventivní. Stále existuje významný rozdíl $\mathrm{v}$ počtu implantací na jeden milion obyvatel mezi USA a zeměmi Evropské unie ( 580 k 220). Primárně-preventivní indikace ICD budou postupně převládat nad sekundárně preventivními indikacemi.

\section{Indikace lázeňské léčby}

Lázeňská péče není u pacientů s implantovaným kardiostimulátorem, ICD, resp. SRL indikována.

\section{Organizace péče $\checkmark$ oblasti TKS a ICD}

\subsection{Trvalá kardiostimulace}

\subsection{1.}

TKS (implantace za hospitalizace nebo ambulantně, sledování nositelů kardiostimulátorů) je organizována na kardiologickém nebo interním oddělení nemocnic $s$ nepřetržitým kardiologickým provozem. Akreditace pro nově vznikající pracoviště je udělována Českou kardiologickou společností na základě doporučení výboru pracovní skupiny Arytmie a trvalá kardiostimulace ČKS (PS AKS ČKS). Funkční licence pro výkony jsou udělovány akreditovanými školiteli pracovišt', určených ke školení těchto výkonů, kteří jsou evidováni Českou lékařskou komorou. Udělení licence je dále evidováno výborem PS AKS ČKS, u dětských kardiologů skupinou dětské kardiologie ČKS. Licence se uděluje jednak pro kardiologickou činnost v souvislosti s kardiostimulací (F11), jednak pro chirurgickou činnost (F12).

\subsection{2.}

Licence pro kardiologickou činnost pro trvalou kardiostimulaci (F11) opravňuje $\mathrm{k}$ indikaci TKS, výběru typu kardiostimulátoru, zavedení stimulační elektrody a měření stimulačních parametrů a ke sledování pacientů s kardiostimulátory. Licenci mohou získat pouze lékaři s atestací z kardiologie. Musejí absolvovat šestiměsíční praxi $\mathrm{v}$ akreditovaném kardiostimulačním centru a předložit následující doklady, potvrzené vedoucím akreditovaného kardiostimulačního centra:

> jmenný seznam nejméně 50 nemocných, u nichž prováděli kardiologickou část implantace,

> jmenný seznam pacientů, u kterých byla provedena samostatná ambulantní kontrola kardiostimulátoru (nejméně 200 nemocných, včetně programování a měření stimulačního prahu),

> jmenný seznam pacientů, u kterých bylo provedeno minimálně deset samostatně provedených základních elektrofyziologických vyšetřeních (testování funkce sinusového uzlu + hisogram) nitrožilní cestou,

> ve všech případech musí být doloženo písemné potvrzení vedoucího pracoviště.

\subsection{3.}

Licence pro chirurgickou činnost pro trvalou kardiostimulaci (F12) opravňuje k provedení chirurgické části implantace a řešení chirurgických komplikací. Licenci mohou získat lékaři s atestací $\mathrm{z}$ chirurgie I. stupně nebo lékaři $\mathrm{s}$ atestací $\mathrm{z}$ kardiologie. Musejí absolvovat minimálně dvouměsíční praxi v akreditovaném kardiostimulačním centru a předložit následující doklady, potvrzené vedoucím akreditovaného kardiostimulačního centra:

> jmenný seznam nejméně 50 pacientů, u nichž provedli implantaci jako první operatér,

> jmenný seznam komplikací vyžadujících chirurgické ošetření.

\subsection{4.}

Pro udělení licence pro kardiologickou a chirurgickou činnost pro TKS v dětském věku může být akceptován po schválení skupinou dětské kardiologie ČKS a PS AKS ČKS nižší počet provedených výkonů, než je uvedeno v bodech 7.1.2. a 7.1.3.

7.1.5.

Podmínky akreditace kardiostimulačního centra

> Přístrojové vybavení kardiostimulačního střediska včetně sálu s rentgenovou skiaskopií,

> nejméně dva lékaři s licencí pro kardiologickou činnost pro trvalou kardiostimulaci,

> nejméně dva lékaři s licencí pro chirurgickou činnost pro trvalou kardiostimulaci,

> nepřetržitý provoz $s$ možností řešení život ohrožujících stavů souvisejících s kardiostimulací (včetně chirurgického oddělení s nepřetržitým provozem),

> v dětské kardiologii je možno požadované počty lékařuo s licencí a počty pacientů upravit na základě schválení pracovní skupiny dětské kardiologie a PS AKS ČKS,

> pracoviště provádějící SRL musí být vybaveno rentgenovým systémem s angiografickou kvalitou zobrazení s možností interpretace šikmých projekcí a dále základním elektrofyziologickým záznamovým zařízením,

> minimálně 50 výkonů TKS ročně,

> pracoviště má povinnost poskytnout hlášení o implantaci, resp. reimplantaci KS do Národního registru kardiostimulátorů (od roku 2009 postupně zaváděná internetová forma registru ve spolupráci s Institutem biomedicínských analýz Masarykovy univerzity v Brně).

Pracoviště, které nesplňuje výše uvedená kritéria, by nemělo implantace kardiostimulátorů provádět a nemělo by získat smlouvu od zdravotních pojištoven.

Seznam akreditovaných pracovišt pro trvalou kardiostimulaci bude umístěn na webových stránkách České kardiologické společnosti - www.kardio-cz.cz

7.1.6.

Organizace kardiostimulační ambulance

Základní podmínky organizace práce v kardiostimulační ambulanci jsou uvedeny v tabulce 7.1.6.1. 
Tabulka 7.1.6.1.

1. Nutnost vést raádně aktualizované lékařské záznamy o pacientech, včetně těchto údajů: demografických údajů, anamnézy, informací o EKG a elektrofyziologickém vyšetření, implantačních a dlouhodobých změnách naprogramovaných parametrů sensingu a stimulačních parametrů.

2. Archivování informací týkajících se generátorů, elektrod a programovacích prístrojů.

3. Vydání evropské registrační karty pro každého pacienta.

4. Poskytování nejaktuálnějšího školení všem klinickým pracovníkům.

5. Pravidelné poskytování obecných i podrobných informací pacientům.

6. Poskytování přiměřených informací ohledně pacientů s kardiostimulátory všem lékařům.

7. Informování oficiálních státních organizací o implantacích kardiostimulátorů, jejich poruchách a prípadech jejich vyjmutí.

\subsection{7.}

Vznik nového centra pro TKS

PS AKS nepovažuje $\mathrm{v}$ současné době za účelné další rozšiřování počtu center. Př́ípadný vznik nového centra pro TKS je podmíněn souhlasem výboru PS AKS, souhlasem výboru ČKS a souhlasem zdravotních pojištoven s nutností zohlednění rovnoměrného regionálního rozložení center.

\section{2. Implantabilní kardiovertery-defibrilátory}

\subsection{1.}

\section{Úvod}

Nejdůležitější pro implantaci implantabilních kardioverterů-defibrilátorů (ICD) je adekvátní zkušenost pracoviště s komplexní srdeční elektrofyziologií, diferenciální diagnostikou tachykardií a katetrizačními ablacemi poruch srdečního rytmu a s úzkou vazbou na pracoviště intervenční kardiologie a kardiochirugické zázemí daného centra.

Tyto zkušenosti a komplexnost přístupu jsou považovány za nezbytné pro určení správné diagnózy, léčby a zvládnutí maligních arytmií, a dále pro správnost prezentované indikace $\mathrm{k}$ implantaci ICD.

Technickou erudici k samotnému implantačnímu výkonu lze získat na základě dostatečného počtu implantovaných kardiostimulátorů a zkušeností se SRL.

Třetí závažnou podmínkou je existence minimálně dvou erudovaných lékařů na pracovišti pro jednotlivé výkony nebo jejich části (funkční licence F11, F12, F13 a F14 - podle bodu 7.2.3), zaručující nepřetržitý servis a také kontinuitu pracoviště po př́padném odchodu jednoho $\mathrm{z}$ nich.

\subsection{2.}

Současný stav péče v oblasti léčby pomocí ICD

V současné době je v České republice 15 center akreditovaných $\mathrm{k}$ implantaci ICD podle původních podmínek vypracovaných výborem PS AKS ČKS a schválených výborem ČKS:

Klinika kardiologie, IKEM, Praha, Kardiologické oddělení, Nemocnice Na Homolce, Praha, II. interní klinika kardio- logie a angiologie, VFN a 1. LF UK, Praha, II. interní klinika, FNKV a 3. LF UK, Praha, Dětské kardiocentrum, FN Motol, Praha, I. interní klinika, FN Hradec Králové a LF UK, I. interní kardioangiologická klinika, FN u sv. Anny a LF MU, Brno, I. interní kardiologická klinika, FN a LF MU, Brno, I. interní klinika, FN Olomouc a LF UP, Interní klinika, FN Ostrava, Kardiologické oddělení Nemocnice Podlesí Třinec, Kardiologické oddělení Krajské nemocnice Pardubice, Kardiologické oddělení Krajské nemocnice Ústí nad Labem, Kardiologické oddělení Krajské nemocnice Liberec, Kardiologické oddělení Krajské nemocnice České Budějovice.

Úroveň péče o pacienty je zajištována níže uvedenými body 7.2.2.1. a 7.2.2.2.

\subsubsection{1}

Každá indikace ICD je posuzována Meziústavní indikační komisí (MIK), která je tvořena lékaři $\mathrm{z}$ akreditovaných center (po jednom hlasu z každého centra), a která zodpovídá za indikace ICD podle již dřive schváleného mechanismu. Po zavedení elektronické formy registru ICD bude posuzování indikací MIK nahraženo možností kontroly údajů $\mathrm{z}$ registru orgány zdravotních pojištoven.

\subsubsection{2.}

Kontrola činnosti center je dále zajištěna povinností pravidelných ročních hlášení center a povinností zasílání registračních karet o implantaci do Národního registru ICD. Tato povinost zaniká s ustanovením elektronického registru ICD. Mění se na povinnost přispívat pravidelně do elektronického registru ICD. MIK vypracuje každý rok hodnotící zprávu o činnosti implantačních center, kterou předloží výboru PS AKS ČKS. Kritérii hodnocení činnosti center jsou počet implantací, počet komplikací a počet správných indikací (dodržování bodu 4.14. těchto Zásad). Při zjištění systematických nedostatků navrhne MIK výboru PS AKS ČKS důkladné přezkoumání až případné zrušení další činnosti centra.

\subsection{3}

Vzhledem $\mathrm{k}$ výše uvedeným faktům byly vypracovány následující podmínky $\mathrm{k}$ udělení akreditace pro implantace ICD u nově vznikajícího centra:

1. Žádost centra o akreditaci musí být schválena výborem PS AKS, je předložena výboru ČKS ke konečnému schválení, a dále postoupena ústředí jednotlivých zdravotních pojištoven.

2. Při schvalování vzniku nového centra je nezbytné přihlédnout ke schválenému Národnímu kardiovaskulárnímu programu a rovnoměrnému regionálnímu rozložení implantačních center v České republice.

3. Akreditační kritéria pro pracoviště žádající o implantace ICD:

a) Funkční komplexní elektrofyziologická laboratoŕ provádějící katetrizační ablace se zkušeností v diferenciální diagnostice tachykardií, s programovanou stimulací komor s vyvolatelností a terminací setrvalých hemodynamicky závažných komorových tachykardií podle standardního protokolu. 
Na pracovišti musí v době žádosti pracovat minimálně dva lékaři s licencí pro diagnostickou elektrofyziologii (F13), z toho nejméně jeden lékař s licencí pro katetrizační ablace (F14), z nichž každý musí prokázat minimálně 100 elektrofyziologických vyšetrení obsahujících programovanou stimulaci komor a nositel licence F13 provedení minimálně 50 katetrizačních ablací jako první vyšetřující.

Tato vyšetření mohou být provedena daným lékařem na různých pracovištích. Je nutné předložit seznam a celkový počet výkonů s daty jednotlivých výkonů a jmény nemocných, přičemž jméno nemocného se při opakovaném vyšetření může opakovat. Tento seznam musí být potvrzen přednostou pracoviště, na kterém byly výkony provedeny, a podepsán lékařem provádějícím vyšetření.

b) Minimálně 100 primoimplantací kardiostimulátorů ročně, provedených ve zdravotnickém zařízení, jehož pracoviště žádá o akreditaci (implantace mohou být prováděny bud' na chirurgickém oddělení nebo př́mo na interním či kardiologickém pracovišti, které žádá o akreditaci). Na pracovišti musí být $\mathrm{v}$ době žádosti minimálně dva lékaři s licencí pro trvalou kardiostimulaci (F11, F12). Seznam výkonů musí být potvrzen přednostou pracoviště, na kterém byly výkony provedeny, a podepsán lékařem provádějícím vyšetření.

c) Zkušenosti s prováděním SRL (minimálně samostatně provedených 30 výkonů). Seznam výkonů musí být potvrzen přednostou pracoviššè, na kterém byly výkony provedeny, a podepsán lékařem provádějícím vyšetření.

d) Podmínkou je nepřetržitý provoz oddělení s možností řešení život ohrožujících stavů v souvislosti s maligními komorovými arytmiemi a ICD.

4. Vedoucí nově akreditovaného centra se automaticky stává členem MIK. Po zrušení MIK zodpovídá vedoucí centra za příspěvky do elektronické formy registru ICD.

\section{Literatura}

1. Vardas EP, Aurcchio A, Blanc JJ, et al. Guidelines for cardiac pacing and cardiac resynchronization therapy. Eur Heart J 2007;28:2256-95.

2. Epstein $A E$, DiMarco $J P$, Ellenbogen $K A$, et al. ACC/AHA/HRS guidelines for device based therapy of cardiac rhythm abnormatilies. J Am Coll Cardiol 2008;51:el-62.

3. Táborský M, Kautzner J, Bytešník J, et al. Zásady pro implantace kardiostimulátorů, implantabilních kardioverterů-defibrilátorů a srdečni resynchronizační léčbu. Cor Vasa 2005; 47 (Suppl 9):59-68.

4. Elmqvist $\mathrm{R}$, Senning A. Implantable pacemaker for the heart. In: Smyth CN, ed. Medical Electronics. Proceedings of the Second International Conferrence on Medical Electronics. Paris, 24-27 June 1959. London, UK: lliffe et Sons, 1960:253-4 [Abstract].

5. Lüderitz B. We have come a long way with device therapy: Historical perspectives on antiarrhythmic electrotherapy. J Cardiovasc Electrophysio 2002;13 (Suppl 1):S2-S8.

6. Ferrer I. The Sick Sinus Syndrome. Mt Kisco, NY: USA Futura Publishing Inc., 1974

7. Fairfax $A J$, Lamber $C D$, Leatham A. Systemic embolism in chronic sinoatrial disorder. New Engl J Med 1976;295:1455-8.

8. Sanchez-Quintana D, Cabrera JA, Farre J, Climent V, Anderson RH, Ho SY Sinus node revisited in the era of electroanatomical mapping and catheter ablation. Heart 2005;91:189-94.

9. Rubenstein JJ, Schulman CL, Yurchak PM, et al. Clinical spectrum of the sick sinus syndrome. Circulation 1972;46:5-13.
10. Kay R, Estioko M, Wiener I. Primary sick sinus syndrome as an indication for chronic pacemaker therapy in young adults: incidence, clinical features, and long-term evaluation. Am Heart J 1982;103:338-42.

11. Shaw DB, Holman RR, Gowers Jl. Survival in sinoatrial disorder (sick sinus syndrome). Br Med J 1980;280:139-41.

12. Lichstein $E$, Aithal $H$, Jonas $S$, et al. Natural history of severe sinus bradycardia discovered by 24 hour Holter monitoring. Pac Clin Electrophysiol 1982;5:185-9.

13. Fuster V, Ryden LE, Cannom DS, et al. ACC/AHA/ESC 2006 guidelines for the management of patients with atrial fibrilation: a report of the American College of Cardiology/American Heart Association Task Force on practice guidelines, the European Society of Cardiology Committee for Practice Guidelines (Writing Committee to Revise the 2001 guidelines for the management of patients with atrial fibrillation) developed in collaboration with the European Heart Rhythm Association, the Heart Rhythm Society. Europace 2006;8:651-745.

14. Connolly SJ, Kerr C, Gent M, et al. Dual-chamber versus ventricular pacing. Critical appraisal of current data. Circulation 1996;94:578-83.

15. Rinfret S, Cohen DJ, Lamas GA, et al. Cost-effectiveness of dual-chamber pacing compared with ventricular pacing for sinus node dysfunction. Circulation 2005;111:165-72.

16. Dretzke J, Toff WD, Lip GYH, Raftery J, Fry-Smith A, Taylor R. Dual chamber versus single chamber ventricular pacemakers for sick sinus syndrome and atrioventricular block. Cochrane Database of Systematic Reviews 2004;2, Art. No. CD003710.

17. Johansson BW. Complete heart block: a clinical, hemodynamic and pharmacological study in patients with and without an artifical pacemaker. Acta Med Scand 1966;180 (Suppl 451):1.

18. Hindman MC, Wagner GS, JaRo M, et al. The clinical significance of bundle branch block complicating acute myocardial infarction: indications for temporary and permanent pacemaker insertion. Circulation 1978;58:689-99.

19. Connely DT, Steinhaus DM. Mobitz type I atrioventricular block: an indication for permanent pacing? Pac Clin Electrophysiol 1996;19:261-4.

20. Shaw DB, Gowers Jl, Kekwick CA, New KHJ, Whistance AWT. Is Mobitz type I atrioventricular block benign in adults? Heart 2004;90:169-74.

21. Ranganathan N, Dhurandhar R, Philips JH, et al. His bundle electrogram in bundle-branch block. Circulation 1972;45:282-94.

22. Barold SS. Indications for permanent cardiac pacing in first degree AV block: class I, II, or III? Pac Clin Electrophysiol 1996;19:747-51.

23. Meine TJ, Al-Khatib SM, Alexander JH, et al. Incidence, predictors, and outcomes of high-degree atrioventricular block complication acute myocardial infarction treated with thrombolytic therapy. Am Heart J 2005;149: 670-4.

24. Behar S, Zissman E, Zion M, et al. Complete atrioventricular block complicating inferior acute wall myocardial infarction: short- and long-term prognosis. Am Heart J 1993;125:1622-7.

25. Domenighetti G, Perret C. Intraventricular conduction disturbances in acute myocardial infarction: short- and long-term prognosis. Eur J Cardiol 1980;11: 51-9.

26. Behar S, Zissman E, Zion M, et al. Prognostic significance of second degree atrioventricular block in inferior wall acute myocardial infarction. Am J Cardiol 1993;72:831-4.

27. Petrac D, Radic B, Birtic K, et al. Block induced by atrial pacing in the presence of chronic bundle branch block. Paci Clin Electrophysiol 1996;19: 784-92.

28. Ezri M, Lermann BB, Marchlinski FE, et al. Electrophysiologic evaluation of syncope in patients with bifascicular block. Am Heart J 1983;106:693-7.

29. Stevenson WG, Perloff JK, Weiss JN, et al. Facioscapulohumeral muscular dystrophy: evidence for selective, genetic electrophysiologic cardiac involvement. J Am Coll Cardiol 1990;15:292-9.

30. Charles R, Holt S, Kay JM, et al. Myocardial ultrastructure and the development of atrioventricular block in Kearns-Sayre syndrome. Circulation 1981;63:214-9.

31. Von Maur K, Nelson EW, Holsinger JW, et al. Hypersensitive carotid syndrome treated by implantable cardiac pacemaker. Am J Cardiol 1972;29: 109-10.

32. Madigan NP, Flaker GC, Curtis JJ, et al. Carotid sinus hypersensitivity: benefical effects of dual-chamber pacing. Am J Cardiol 1984;53: 1034-40.

33. Morley CA, Perrins EJ, Grant PL, et al. Carotid sinus syncope treated by pacing. Analysis of persistent symptoms and role of atrioventricular sequential pacing. Br Heart J 1982;47:411-8.

34. Sungrue DD, Gersh BJ, Holmes DR, et al. Symptomatic 'isolated' carotid sinus hypersensitivity: natural history and results of treatment with anticholinergic drugs or pacemaker. J Am Coll Cardiol 1986;7:158-62. 
35. Young T, Palta M, Dempsey J, et al. Thye occurrence of sleep-disordered breathing among middle-aged adults. N Engl J Med 1993;328: 1230-5.

36. Shahar E, Whitney CW, Redline S, et al. Sleep-disordered breathing and cardiovascular disease: cross-sectional results of the Sleep Heart Health Study. Am J Respir Crit Care Med 2001;163:19-25.

37. Peker $\mathrm{Y}$, Hedner J, Kariczi $\mathrm{H}$, et al. Respiratory disturbance index: an independent predictor of mortality in coronary artery disease. Am J Respir Crit Care Med 2000;162:81-6.

38. Silvetti MS, Drogo F, Grutter G, et al.Twenty years of paediatric cardiac pacing: 515 pacemakers and 480 leads implanted in 292 patients. Europace 2006;8:530-6.

39. Cohen Ml, Buck K, Tanel R, et al. Capture management efficaces in children and young adults with endocardial and unipolar epicardial systems. Europace 2004;6:248-55.

40. Walker F, Siu SC, Woods S, et al. Long-term outcomes of cardiac pacing in adults with congenital heart disease. J Am Coll Cardiol 2004;43: 1894-901.

41. Michaelson M, Jonzon A, Riesenfeld T. Isolated congenital complete atrioventricular block in adult life. A prospective study. Circulation 1995;92:442-9.

42. Janoušek J, Tomek V, Chaloupecký VA, et al. Cardiac resynchronization therapy: a novel adjunct to treatment and prevention of systemic right ventricular failure. J Am Coll Cardiol 2004;44:1927-31.

43. Driscoll DJ, Edwards WD. Sudden unexpected death in children and adolescents. J Am Coll Cardiol 1985;5 (Suppl 6):118B-21B.

44. Thaulow $E$, Webb G, Hoffman A, et al. Task Force on the management of grown up congenital heart disease of the European Society of Cardiology. Eur Heart J 2003:24:1035-84.

45. Walsh EP, Cecchin F. Recent advances en pacemaker and implantable defibrillator therapy for young patients. Curr Opin Cardiol 2004;19:91-6.

46. Berul C, Cecchin F. Indications and techniques of pediatric cardiac pacing. Expert Rev Cardiovasc Ther 2003;1:165-76.

47. Kavey RE, Gaum WE, Byrum CJ, et al. Loss of sinus rhythm after total cavopulmonary connection. Circulation 1995;92(Suppl.9):II304-8.

48. Miyomato $Y$, Curtiss $E$, Kormos $R$, et al. Bradyarrhytmias after heart transplantation. Circulation 1990;82 (Suppl IV):313-7.

49. DiBiase A, Tse TM, Schnittger I, et al. Frequency and mechanism of bradycardia in cardiac transplant recipients and need for pacemakers. Am J Cardiol 1991:67:1385-9.

50. Holt ND, McComb JM. Cardiac transplantation and pacemakers: when and what to implant? CEPR 2002;6:140-51.

51. Jeanrenaud X, Goy JJ, Kappenberger L. Effects of dual chamber pacing in hypertrophic obstructive cardiomyopathy. Lancet 1992;339:1318-23.

52. Prinzen FW, van Oosterhour MFM, Delhaas $T$, et al. Epicardial ventricular pacing at physiological heart rate leads to assymetrical changes in left ventricular wall thickness. Eur Heart J 1994;15 (Suppl):76.

53. Pak PH, Maughan L, Baughman KL, et al. Mechanism of acute mechanical benefit from VDD pacing in hypertrophied heart similarity of responses in hypertrophic cardiomyopathy and hypertensive heart disease. Circulation 1998;98:242-8.

54. Gadler F, Linde C, Ryden L. Rapid return of left ventricular outflow tract obstruction and symptoms following cessation of long-term atrioventricular synchronous pacing for obstructive hypertrophic cardiomyopathy. Am J Cardiol 1999;83:553-7.

55. Patel $P$, Hussain W, Linde $C$, et al. Pacing increases Connexin 43 expression in patients with hypertrophic cardiomyopathy. Heart Rhythm 2004;1:S22.

56. Kappenberger L, Linde C, Daubert JC, et al, and the Pacing in Cardiomyopathy (PIC) Study Group. Pacing in hypertrophic obstructive cardiomyopathy - a randomised crossover study. Eur Heart J 1997;18:1249-56.

57. Maron BJ, Nishimura RA, McKenna WJ, et al, for the M-PATHY Study Investigators. Assessment of permanent dual-chamber pacing of a treatment for drug-refractory symptomatic patients with obstructive hypertrophic cardiomyopathy. Circulation 1999;99:2927-33.

58. Gadler F, Linde C, Juhlin-Dannfelt A, Ribeiro A, Ryden L. Long term effects of dual chamber pacing in patients with hypertrophic obstructive cardiomyopathy without outflow obstruction at rest. Eur Heart 1997;18:639-42.

59. Hawkins NM, Petrie MC, MacDonald MR, Hogg KJ, McMurray JJV. Selecting patients for cardiac resynchronisation therapy: electrical or mechanical dyssynchrony? Eur Heart J 2006;27:1270-81.

60. Lecrercq $C$, Hare J. Ventricular resynchronization. Current state of the art Circulation 2004;10:296-9.

61. Bleeker G, Schalij, Molhoek A, et al. Frequency of left ventricular dyssynchrony in patients with heart failure and a narrow QRS complex. Am J Cardiol 2005;95:140-2.
62. Ghio S, Constantin C, Klersy, C, et al. Interventricular and intraventricular dysynchrony are common in heart failure patients, regardless of QRS duration. Eur Heart J 2004;25:571-8.

63. Bax J J, Gorcsan J. Echocardiography and noninvasive imaging in cardiac resynchronization therapy. Results from the PROSPECT Study in perspective. J Am Coll Cardiol 2009;53:1933-43.

64. Zipes DP, Camm AJ, Borggrefe M, et al. ACC/AHA/ESC 2006 Guidelines for management of patients with ventricular arrhythmias and the prevention of sudden cardiac death. Circulation 2006;114:e385-e484.

65. Glikson M, Dearani JA, Hyberger LK, et al. Indications, effectiveness, and long-term dependency in permanent pacing after cardiac surgery. Am J Cardiol 1997;80:1309-13.

66. DiBiase A, Tse TM, Schnittger I, et al. Frequency and mechanism of badycardia in cardiac transplant recipients and need for pacemakers. Am J Cardiol 1991;67:1385-9.

67. Kuck KH, Cappato R, Sibels J, et al. Randomized comparison of antiarrhytmic therapy with implantable defibrillators in patients resuscitated from cardiac arrest. The Cardiac Arrest Study Hamburg (CASH). Circulation 2000;102: 748-53.

68. The Antiarrhythmia Versus Implantable Defibrillators (AVID) Investigators: A comparison of antiarrhytmic - drug therapy with implantable defibrillators in patients resuscitated from near-fatal ventricular arrhytmias. N Engl J Med 1997;337:1576-83.

69. Connoly SJ, Gillis AM, Lacombe P et al. Canadian Implantable Defibrillator Study (CIDS). Circulation 2000;101:1297-302.

70. Moss AJ, Hall WJ, Cannom DS, et al. Improved survival with an implanted defibrillator in patients with coronary disease at high risk for ventricular arrhytmia (MADIT). N Engl J Med 1996;335:1933-40.

71. Moss AJ, Zareba W, Hall J, et al. Prophylactic implantation of a defibrillator in patients with myocardial infarction and reduced ejection fraction. $N$ Engl J Med 2002;346:877-83.

72. Buxton $A E$, Lee $K L$, Fischer JD, et al. A randomized study of the prevention of sudden death in patients with coronary artery disease (MUSTT). N Engl J Med 1999;341:1882-90.

73. Wewer EF, Hauner RN, Schrijvers G, et al. Cost-effectiveness of implantable defibrillator as first-choise therapy versus electrophysiology guided, tiered strategy in postinfarct sudden death survivors. A randomized study. Circulation 1996:93:489-96.

74. Bardy GH, Lee KL, Mark DB, et al. Sudden Cardiac Death in Heart Failure Trial (SCD-HeFT) Investigators: amiodarone or an implantable cardioverter-defibrillator for congestive heart failure. N Engl J Med 2005;352: 225-37.

75. Kadish A, Dyer A, Daubert JP, et al. Prophylactic defibrillator implantation in patients with nonischemic dilated cardiomyopathy. N Engl J Med 2004; 350:2151-8.

76. Strickberger SA, Hummel JD, Barlett TG, et al. Amiodarone versus implantable cardioverter-defibrillator: randomized trial in patients with non-ischemic dilated cardiomyopathy and asymptomatic non-sustained ventricular tachycardia - AMIOVIRT. J Am Coll Cardiol 2003:41: 1707-12.

77. Bansch D, Antz M, Boczor S, et al. Primary prevention of sudden cardiac death in idiopathic dilated cardiomyopathy: the Cardiomyopathy Trial (CAT). Circulation 2002;105:1453-8

78. Rivero-Ayerza M, Theuns D, Garcia-Garcia HM, Boersma E, Simoons M, Jordaens LJ. Effects of cardiac resynchronization therapy on overall mortality and mode of death: a meta-analysis of randomized controlled trials. Eur Heart J 2006;27:2682-8.

79. Auricchio A, Metra M, Gasparini M, et al, for the Multicenter Longitudinal Obserrvational Study (MILOS) Group. Long-term survival of patients with heart failure and ventricular conduction delay treated with cardiac resynchronization therapy. Am J Cardiol 2007;99:232-8.

80. Gasparini $M$, Bocchiardo $M$, et al. Comparison of 1 year effects of left ventricular and biventricular pacing in heart failure patients with ventricular arrhytmias and left bundle-branch block: the BELIEVE (bi vs left ventricular pacing: an international pilot evaluation on heart failure patients with ventricular arrhythmias) multi-center prospective randomized pilot study. Am Heart J 2006;152:e1-e7.

81. Wilkoff BL, Cook JR, Epstein $A E$, et al. Dual-chamber or ventricular backup pacing in patients with an implantable defibrillator: the dual Chamber and VVI Implantable Defibrillator (DAVID) Trial. JAMA 2002;288:3115-23.

82. Gras $D$, Böcker $D$, Lunati $M$, et al, on behalf of The CARE-HF Study Steering Committee and Investigators. Implantation of cardiac resynchronization therapy systems in the CARE-HF trial: procedural success rate and safety. Europace 2007;9:516-22.

83. Prystowsky EN. Primary prevention of sudden cardiac Death. The time of your life. Circulation 2004;109:1073-5. 